\title{
Development of Learning Craft Arts Online, Collaboration of Kamon Tachibana mon and Mandailing Bona Fur Carvings on Cushions and Tablecloths Couches
}

\author{
Netty Juliana \\ Faculty of Engineering, Fashion Design Education Study Program, State University of Medan (Indonesia)
}

\begin{abstract}
This research is in the form of the development of learning craft art online in the collaboration of kamon ornaments and North Sumatra carvings on sofa cushions and tablecloths products. The methodology used in this research is descriptive quantitative with a Likert scale. The purpose of this research is to develop learning craft art online using a learning management system (LSM). The results of the evaluation of learning craft art online are as follows; media google classroom 86\%; google media meet $87 \%$; art and craft material $75 \%$; materials designing craft products in general $76 \%$; sequin sofa craft concept on flowchart $76 \%$; sofa sequin craft concept on paper 77\%; sofa craft sketches cushions and tablecloths $80 \%$; design motifs and sofa products cushions and tablecloths $79 \%$; sofa craft products cushions and tablecloths $81 \%$; and the presentation of sofa craft products cushions and tablecloths $79 \%$.
\end{abstract}

Keywords: learning, crafts, online, sofa pillowcases

\section{INTRODUCTION}

L earning is a process of teaching and learning activities between educators and students. Educators plan and carry out a process of learning activities based on a well-designed and systematic curriculum. Educators provide guidance and training intensively, patiently and responsibly. Educators perform community service, for educators in higher education. Furthermore, educators evaluate students through written or practical exams. So that an educator conducts an evaluation through research carried out during the learning process.

[2] Online learning is a teaching-learning process that is carried out online via the internet using a learning management system (LSM), zoom cloud meet, google meet and so on. So that online learning can be said to be an internet network-based teaching and learning process. This learning is carried out by educators in transferring learning material, giving students daily assignments, evaluating student learning, and evaluating competence in each instrument or indicator carried out by the teacher in teaching each subject.

Based on the 2013 curriculum, learning evaluation is an assessment of each stage of the overall learning activity, but not only assessing student learning outcomes.[3] Art is a part of culture that develops dynamically psychological problems. By seeing / hearing / feeling what is presented in an art, humans can at least be entertained and at least can be more refreshing to the mind that has been burdened by various kinds of life problems. What should be questioned is what kind of art is able to refresh the human psychic condition?

Art has 3 supporting elements, namely artists, viewers or critics, and works of art. Artists are divided into two types, namely creative artists and interpretative artists. Artists with their creative experiences contain two sides, namely the subjective side and the objective side. The subjective side is very much influenced by various psychological factors, such as sensitivity, imagination, personal character, desires, and various experiences in particular. The objective side is influenced by environmental factors, such as the physical environment, value systems, the influence of traditions, social needs, materials or materials, the cultural climate of Jazuli (2001: 81-83).

[4] Collaboration can be defined as the addition of another form in an art with the aim that the craft art can attract the audience more without leaving the aesthetic value and meaning of the art itself. In principle, craft art collaborations will produce innovative art products, so the resulting art products will be more adaptive. This can be done through a collaborative process of kamon ornament and North Sumatra ornament on household linen craft products that produce new, unique, and creative products.

[5] Research activities in the Fashion Design Program of the State University of Medan carry out activities to develop sofa cushions and tablecloth crafts. The manufacture of household items applies North Sumatran patterns in collaboration with Japanese Kamon patterns using various kinds of sequins. So that research has a positive impact on students and teachers to be creative, innovative, and adaptive. Students develop skills and acquire knowledge in the field of sofa cushions and tablecloth crafts.

\section{RESEARCH METHODS}

This study uses a quantitative descriptive approach to analyze how the ability to develop learning practice of craft art online, especially the collaboration of Kamon and North Sumatra 
ornaments on sofa cushions and tablecloths craft products for students of the fashion design study program at Unimed in the 2020 academic year.

The population and sample of the study were 100 students of the Unimed Fashion Department in the academic year 2020, with the consideration that the students studied were students who were taking craft arts lectures.

Based on purposive sampling technique and Slovin technique in sampling, it is known that the number is 29 people. To collect data, the research was carried out using a questionnaire instrument (questionnaire). The questionnaire is compiled and developed in accordance with the indicators of the 10ability variables needed in the job market, the indicators are then compiled based on a theoretical study put forward by expertsthen developed into questions. By using a modified Likert scale in accordance with the measurement indicators with a measurement scale of the effectiveness of the model that has been designed and has been applied in the learning process.

Data analysis was performed using percentage techniques and categorization with the formula:

$$
\begin{array}{ll}
\text { Acquisition Total } & \text { X100 }
\end{array}
$$

The highest answer $\mathrm{x}$ number of respondents $\mathrm{x}$ Number

The results of the analysis are based on the formula above, then categorize the results of the respondents' level of achievement based on a scale. Sudjana (1996) according to the following table 1 :

Table I. Scale

\begin{tabular}{|c|c|}
\hline percentage of Achievement & Criteria \\
\hline $90-100 \%$ & Very high \\
\hline $80-89 \%$ & High \\
\hline $65-79 \%$ & moderate \\
\hline $55-64 \%$ & Low \\
\hline $0-54 \%$ & Very low \\
\hline
\end{tabular}

\section{RESULTS AND DISCUSSION}

The results of the study are described based on the average value (mean), the middle value (median), the lowest value (minimum), the highest value (maximum), the total value (sum), the percentage of the respondent's level of achievement and its categories. Following are the results of the evaluation data analysis of the Computer Practice Learning drawing mode.
Table II. The results of data analysis of students of the Unimed Fashion Design Education Study Program

\begin{tabular}{|c|c|c|c|c|c|c|c|c|c|}
\hline $\mathrm{N}_{0}$. & Leaning Eraluation Results & Mean & Idi & Node & Min & Max & Sum & $\%$ & Categong \\
\hline & Google Classroom mefia & 18,11 & 19 & 19 & 15 & 20 & 507 & $86 \%$ & High \\
\hline 2 & Google Neet metia & 22,43 & 23,5 & 24 & 16 & 25 & 628 & $87 \%$ & High \\
\hline 3 & Craft Art Naterials & 15,5 & 16,00 & 16 & 11 & 20 & 434 & $75 \%$ & Moderate \\
\hline 4 & Designing Craft Products & 23,54 & 24,00 & 24 & 18 & 30 & 659 & $76 \%$ & Moderate \\
\hline 5 & Sofa sequin craft concept on forrchart & 19,57 & 20,00 & 20 & 15 & 25 & 548 & $76 \%$ & Moderate \\
\hline 6 & Sofa sequin craft concept on paper & 20,04 & 20,00 & 20 & 15 & 25 & 561 & $77 \%$ & Moderate \\
\hline 7 & Sketch a productimage & 12,46 & 12,00 & 12 & 9 & 15 & 349 & $80 \%$ & High \\
\hline 8 & Cushions \& tablecloths sofa designs \& products & 245 & 24,00 & 24 & 18 & 30 & 686 & $79 \%$ & Moderate \\
\hline 9 & Manufacture of sofa cushions \& tablecloths on materials & 21,07 & 20 & 20 & 15 & 25 & 590 & $81 \%$ & High \\
\hline 10 & Cushions \& Tabledoths Sofa Craft Presentation & 20,57 & 20,00 & 20 & 15 & 25 & 576 & $79 \%$ & Moderate \\
\hline
\end{tabular}

Based on table 2 above shows the results of the ability to evaluate the learning practice of sequin sofa cushions and tablecloths in craft art lectures in the high google classroom media category with a percentage of $86 \%$. The results of google meet media evaluation in craft art lectures are in the high category with a percentage of $87 \%$. The evaluation of student learning on mastery of craft art material falls into the medium category with a percentage of $75 \%$. In general, the evaluation of learning on mastery of material about designing craft products is in the medium category with a percentage of $76 \%$. The results of the evaluation of student learning on the sofa sequin craft concept on the flowchart fall into the medium category with a percentage of $76 \%$. The evaluation of student learning on the sofa sequin craft concept on the paper is in the medium category with a percentage of $77 \%$. The results of the learning evaluation on sofa cushions and tablecloths craft sketches are in the high category with a percentage of $80 \%$. Learning evaluation of motif designs and sofa cushions and tablecloths products is in the medium category with a percentage of $79 \%$. The results of the evaluation of student learning on making sofa cushions and tablecloths craft products fall into the high category with a percentage of $81 \%$. And the results of the evaluation of the results of the presentation of sofa cushions and tablecloths on student learning outcomes are in the moderate category with a percentage of $79 \%$.

Analysis of the data presented, it can be more clearly stated that the results of the research are in the form of the following histogram in Figure 1:

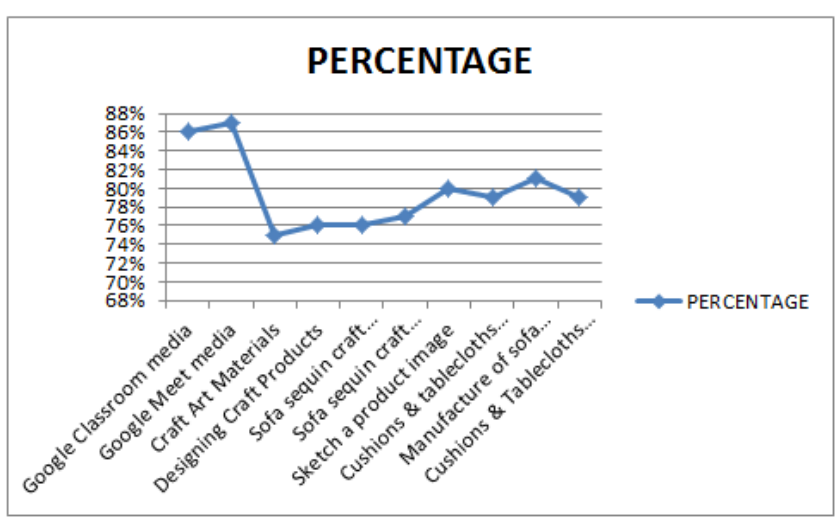

Figure .1 histogram analysis results of the study percentage 
Based on the data analysis described above, it can be concluded that the results of the evaluation of online practical learning in the craft art course have ten indicators, namely google classroom media, google meet media, mastery of craft art material, mastery of material designing craft products, cushions and tablecloths on the flowchart, making sofa sequin craft concepts, cushions and tablecloths on papers, sketches of drawings of craft products, designs of motifs and craft products, the process of making sofa craft products as well as the presentation of the craft products produced by students in a good category. The results of the evaluation of the results of the data above show that learning the art of craft online on sofa cushions and tablecloths products is categorized as being successfully carried out today. Students have been able to create new sequin craft products in the form of sofa cushions and tablecloths that are unique, attractive, innovative, creative and ethnic. The craft product is a collaboration of Kamon ornaments and North Sumatra carving ornaments. Students already have the skills and knowledge in the field of craft and computer design well. So that the skills and knowledge that students have can be needed in the world of the textile, garment and other craft industry.

The results of online learning evaluations in the sequin sofa cushions and tablecloths course on google classroom media indicators, google meet media, and the presentation of craft product results are supporting indicators of the main indicators above, but these indicators are interrelated and related to the variables one other variables. Indicators from google classroom media, google meet media, and presentation of craft products are in good category. So that all the indicators above show the preparation of students for employment. Students are optimally prepared as potential textile and fashion designers. There is great hope that after completing their studies at higher education, students are ready to enter the world of work and students are ready to open new jobs in the textile and interior fashion business in accordance with fashion trends and the needs of today's society.

Figure 2: Mandailing Motif sequin design (collaboration of Kamon Tachibana Mon and Bona Bulu Mandailing Carving)

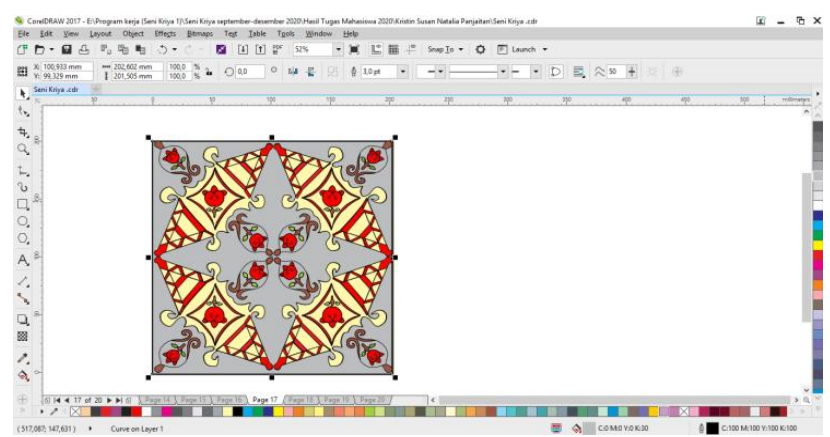

Learning the art of craft is carried out online in designing sofa cushions and tablecloths craft products. Several stages are carried out in the implementation of learning craft art online, namely:
1. Lecturers and students carry out face-to-face online meetings using the zoom cloud media meeting. At the online meeting, the lecturer submits the lecture contract and is continued by delivering material about the theoretical craft art.

2. Students can study independently on the google classroom media which has been agreed upon by educators and students. So,students can learn independently of the teaching materials sent by the lecturer to the craft art class group. The teaching materials presented by the lecturers can be in the form of theoretical presentations on powerpointsand practical materials in the form of videos in designing collaborative Kamon decorative styles with the form of North Sumatra gorga.

3. Students can receive practical assignments and theoretical assignments online through google classrooms delivered by lecturers in the craft arts group. Giving practical assignments and paper assignments to students is done using pdf or microsoft word.

4. Lecturers can provide direct value on each practical assignment and paper assignment on the google classroom media. So that students directly receive the results of each assignment online.

Figure 3: The process of making sofa products for cushions and tablecloths.
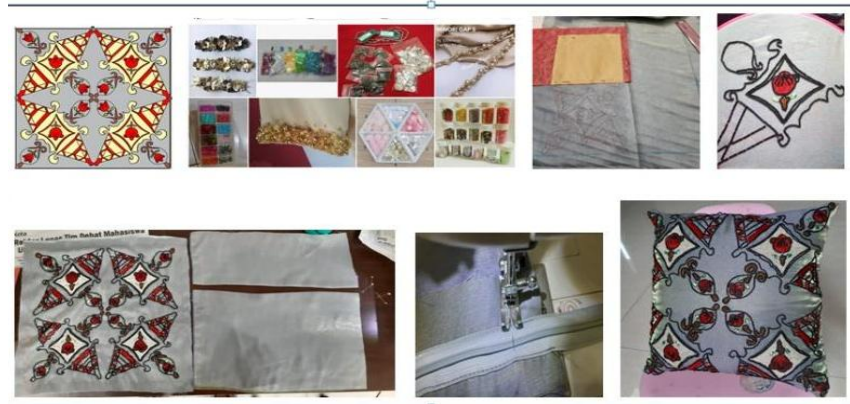

The steps for designing sofa products for cushions and tablecloths on learning the art of craft:

1. Students determine ideas on kamon and gorga ornaments North Sumatra. These ideas are applied into the concept of flow charts.

2. Students prepare sequencing materials and equipment.

3. Students are able to sketch pictures manually with pencil media.

4. Students are able to develop a sketch of a picture into a new motif using CorelDraw media.

5. A new motif is applied to the surface of a plain cloth by drawing a motif on the surface of the plain cloth.

6. The process of attaching or attaching sequins to the fabric using hand thread and needle.

7. Cushions and tablecloths sofa pattern making.

8. Cushions and tablecloths sofa product sewing.

9. The finishing process is ironing the sofa cushions and 
tablecloths so that they are neat.

When viewed from the culture of the Mandailing Batak community, the bona Bulu carving means a forest administration system or a community residential area that already has complete facilities and infrastructure. The kamon ornament Tachibana-mon or Mandarin Orange is a symbol of the fruit and leaves of Tachibana Citrus. Tachibana is evergreen and is known for its great aroma. This kamontachibana-mon symbolizes immortality by Japanese society. The two decorations are ideas for creating new sequin motifs. The result of the collaboration of Tachibana-mon ornaments and Mandailing feather bona carvings

\section{CONCLUSIONS AND SUGGESTIONS}

This research is the development of learning Craft Art online which is a collaboration of Kamon Tachibana mon and Mandailing Bona Fur Carving on Cushions And Tablecloths Couches. The research resulted in students' creativity in craftsmanship. How many things students get in learning craft art online, namely: 1) Students mastering craft learning media online, namely; coreldraw, google classroom, zoom cloud meetings. 2) Students acquire knowledge of textile crafts. 3) Students are able to systematically make concept maps on flowcharts and concepts on papers. And 4) Students are able to learn independently, be creative, and innovative in designing unique sequins on household linen with a background in the development of North Sumatra cultural decorations.

The results of evaluating the ability of online practical learning in craft arts courses for Unimed students showed a good quality improvement with good learning outcomes for students of the fashion design study program. Evaluation of online practical learning abilities in the art of fashion drawing craft using qualitative descriptive research using a Likert scale.

The results of this evaluation consist of ten indicators, namely; 1) The category of learning evaluation results through the Google Classroom is included in the high category with high organization with a percentage of $86 \%$. 2) The results of the evaluation of learning through google meet media in craft art lectures are in the high category with a percentage of $87 \%$. 3) Evaluation of student learning on mastery of craft art material falls into the medium category with a percentage of $75 \%$. 4) Evaluation of learning on mastery of material about designing craft products in general is in the medium category with a percentage of $76 \%$. 5) The results of the evaluation of student learning on the sofa sequin craft concept on the flowchart fall into the medium category with a percentage of $76 \%$.6) Evaluation of student learning on the sofa sequin craft concept in the paper is in the medium category with a percentage of 77\%. 7) The results of the learning evaluation of the product form sketch were in the high category with a percentage of $80 \%$. 8) Evaluation of learning on motif designs and sofa cushions and tablecloths products is in the medium category with a percentage of $79 \%$. 9) The results of the evaluation of student learning on making sofa craft products, cushions and tablecloths fall into the high category with a percentage of $81 \%$. 10) And the results of the evaluation of the presentation of the sofa cushions and tablecloths on student learning outcomes are in the moderate category with a percentage of $79 \%$.

So learning the art of craft online in collaboration with kamon ornaments and carving North Sumatra. Sofa cushions and tablecloths are needed by students to open new jobs in the form of home craft industries and prepare reliable workers in the industrial world such as the garment industry, boutiques, and the textile industry.

\section{SUGGESTION}

It is hoped that students who have taken online craft art practice courses will further develop their creativity in creating craft art designs that are needed by society in accordance with fashion trends. So that students are proficient in designing craft art products using manual techniques and with computer media. So that the skills obtained by students can be needed in the world of business and the world of industrial work.

\section{REFERENCES}

[1] Oktafia I. Handarini. 2020. Online Learning as a Study From Home (SFM) Effort During the Covid Pandemic 19. Journal of Office Administration Education (JPAP).vol 8. no.3.

[2] Randall E Osborne. 2011. It Can Be Taught: Eksplorations into Teaching the Foundations For Multicultural Effectiveness in an Online Course. Paper form IACCP. https://scholarworks.gvsu.edu/iaccp_papers/68/.

[3] Tatiana Chemi. 2017. Arts-based methods in education-A Global Perspective. River Publisher Series in innovation and change in Education. Aalborg University, Denmark.

[4] Catherine E Kerrigan. 2015. The art of collaboration. Journal Researchgate.https://www.researchgate.net/publication/291973072 September.

[5] Jane Fedorowicz. 2008. Creativity,Innovation, and ECollaboration. DOI: $10.4018 / \mathrm{jec} .2008100101$. https://www.researchgate.net/publication/220474984.

[6] Catherine E Kerrigan. 2015. The art of collaboration. JournalResearchgate.https://www.researchgate.net/publication/291 973072 . 